\title{
Reactivity of Brazilian Coal, Charcoal, Imported Coal and Blends Aiming to Their Injection into Blast Furnaces
}

\author{
Janaína Gonçalves Maria da Silva Machado*, Eduardo Osório, Antônio Cezar Faria Vilela \\ Iron and Steelmaking Research Group - LASID, Technology Center, \\ Federal University of Rio Grande do Sul - UFRGS, \\ Av. Bento Gonçalves, 9500, CP 15021, CEP 91501-970, Porto Alegre, RS, Brazil
}

Received: May 14, 2009; Revised: September 17, 2010

\begin{abstract}
For about 10 years the steel industry in Brazil has used pulverized coal injection (PCI) technology in the blast furnaces based on imported coals. In order to decrease the dependence on imported coals, Brazilian coal, which has limited use due to high ash content, was suggested to be mixed with imported coal and charcoal. The aim was to examine the reactivity of the samples. The charcoal use in the steel industry contributes to the $\mathrm{CO}_{2}$ emission reduction, since it represents a renewable source of energy. The reactivity of the coals, charcoal and mixtures was evaluated through simultaneous thermal analyses. Results of this study are presented and discussed.
\end{abstract}

Keywords: Brazilian coal, charcoal, thermogravimetric analysis, reactivity

\section{Introduction}

Pulverized coal injection (PCI) is one of the most effective technologies to reduce coke consumption in the blast furnace $(\mathrm{BF})$. The coal injected into the BF tuyeres can replace up to $40-50 \%$ of the coke required for the process ${ }^{1}$. The average pulverized coal injection rate makes up $130-160 \mathrm{~kg} . \mathrm{t}^{-1}$ hot metal (HM). Several blast furnaces inject 200-220 kg.tHM ${ }^{-1[1]}$. This may leads to a significant decrease in the HM cost due to the considerable difference in price between non-coking coal and coke. The injection of a large amount of pulverized coal has been considered important in recent years as an effective means of coping with the obsolescence of coke ovens, pollution problems, etc.

During the 90's, the steel industry in Brazil started to use PCI in the BFs. Currently the average injection rate is around $140 \mathrm{~kg} \cdot \mathrm{tHM}^{-1[2]}$. Brazil is one of the biggest coal importers; it imports all coal used in the BFs: about 17 million ton per year including 13 million for cokemaking and 4 million for $\mathrm{PCI}^{2,3}$. Therefore, attempts have been made to decrease the dependence on the foreign coals by partially replacing them with national coals. The measured coal reserves in Brazil are about $10 \mathrm{Gt}^{3}$. The largest coal reserves in Brazil are located in southern Brazil. This coal has a rank of sub-bituminous, high contents of inert components, non-coking properties and a high reactivity. The principal use for the coal mined in Brazil is the combustion for power generation. Studies on the properties of this coal have shown that it could be injected into BFs in blends with imported coals ${ }^{4-6}$.

Besides coal, another promising fuel in Brazil is biomass. In recent years, social awareness has been holding movements to reduce the greenhouse gas emissions to prevent global warming. Such social pressure acts strongly on the steel industry due to its huge industrial scale and energy consumption. The use of the biomass resources is one of the ways for $\mathrm{CO}_{2}$ minimization. Biomass resources, like woods, grass, sugarcane, etc., fix $\mathrm{CO}_{2}$ within their body during their growth process. Therefore, with effective use of such biomass, $\mathrm{CO}_{2}$ emitted from the industry is absorbed by them, and a recirculation route of carbon can be formed. In the ironmaking industry, the biomass type charcoal can be used as fuel and reductant. Charcoal plays an important role in Brazil's iron and steel industry. In 2006, about one third of the total HM production, i.e. 10.2 million ton was made in about 153 small charcoal blast furnaces ${ }^{7}$. The production is located in the southeast and northern regions of Brazil. Approximately $94 \%$ of this HM was produced by independent producers (referring to the companies producing only pig iron) and $6 \%$ by the integrated steelworks $^{2}$. In the small charcoal BFs, the injection of fine charcoals has been used for many years. Injection rates make up 100 to $150 \mathrm{~kg} \cdot \mathrm{tHM}^{-1[7]}$. Nowadays, technology for charcoal used as a renewable energy source in the large modern blast furnaces is being developed in the scope of a European steel industry initiative. The aim is to reduce the $\mathrm{CO}_{2}$ emissions to the level where this might be needed in the post-Kyoto period. NOGAMI et al. discussed that the injection of fine charcoals into the BFs tuyeres can reduce more than $30 \%$ of the net $\mathrm{CO}_{2}$ emission compared with the traditional ironmaking process ${ }^{8}$.

Complete combustion of a solid fuel within the BF combustion zone is difficult due to the short residence time (about 20-30 ms) of the fuel particles in this zone ${ }^{9}$. Within such limited times and considering the large fuel injection rates, combustion will invariably be incomplete, meaning that considerable amounts of unburnt particles will escape from the raceway region. In tuyeres and raceways, the pyrolysis of injected coal particles and the combustion of resulting chars occur rapidly. When all injected oxygen is depleted, the main char consuming reaction is gasification by $\mathrm{CO}_{2}$. Mostly, this is thought to take place at the end of the raceway and in the furnace shaft ${ }^{10}$.

There is no standard test for determining the reactivity of coals and their chars to $\mathrm{CO}_{2}$ in regard to PCI performance ${ }^{11}$. Thermogravimetric analysis (TGA) has been used to study the gasification characteristics of chars ${ }^{12-15}$ and also it has been extensively applied to the characterisation of coals, revealing trends in behaviour.

The main target of the present study is to evaluate the reactivity of the Brazilian coal, charcoal, imported coal and blends by TGA. The Brazilian coal, which has limited use due to high ash content, was mixed with charcoal and imported coals in order to minimize the negative effect of some properties. 


\section{Experimental}

\subsection{Samples and their characterisation}

The Brazilian coal used in this work is from Leão-Butiá mine located in the southern part of the country. The charcoal and imported coal were supplied by a Brazilian steel company.

The samples tested were: charcoal (CC), Brazilian coal (BC), imported coal $\mathrm{A}$ and $\mathrm{B}$ (ICA and ICB). The binary blends tested in wt. $(\%)$ were: $50 \%$ BC-50\%CC, $50 \%$ BC-50\% ICA, $50 \%$ BC-50\% ICB, $50 \% \mathrm{CC}-50 \% \mathrm{ICA}, 50 \% \mathrm{CC}-50 \% \mathrm{ICB}$ and $50 \% \mathrm{ICA}-50 \% \mathrm{ICB}$.

Samples were ground to $212 \mu \mathrm{m}$ before blending, then mixtures were prepared by weight and the blend was further ground to $75 \mu \mathrm{m}$.

Proximate analysis (ash, volatile matter, moisture), ultimate analysis, calorific values and Hardgrove Index (HGI) were determined according to standards (ABNT 8289, 8290, 8293, ASTM 5373, D5865, D409). Coal rank of the feed coals was determined by vitrinite reflectance measurement (ISO 7404/5-1984) whereas petrographic composition of the single coals was determined by maceral analysis using standardized procedures (ISO 7404/3-1984). Ash composition was determined by X-ray fluorescence (ASTM D 4326).

\subsection{TGA and test procedure}

The char reactivity towards carbon dioxide was evaluated in a thermogravimetric analyser NETZCH - STA 409. In the first phase of the test (pyrolysis), $30 \mathrm{mg}$ of sample (grounded and sieved to under $75 \mu \mathrm{m}$ ) was heated to $1050{ }^{\circ} \mathrm{C}$ with a heating rate of $30{ }^{\circ} \mathrm{C} /$ $\mathrm{min}$ in nitrogen atmosphere $(50 \mathrm{ml} / \mathrm{min})$. After the removal of volatile matter, the gas atmosphere was switched to $\mathrm{CO}_{2}(50 \mathrm{ml} / \mathrm{min})$; the test was finished after the complete reaction. Conversion degree, i.e, the fraction of the carbon matter that reacts with $\mathrm{CO}_{2}$ and generates $\mathrm{CO}$, was calculated as follows (Equation 1):

$$
X=\frac{\left(m_{0}-m\right)}{\left(m_{0}-m_{c}\right)} \times 100
$$

The reactivity was evaluated according to: $\mathrm{R}=-1 / \mathrm{m}_{0}(\mathrm{dm} / \mathrm{dt})$, where $\mathrm{R}$ is the maximum reactivity, $\mathrm{m}_{0}$ is the ash free mass at $1050{ }^{\circ} \mathrm{C}$ before replacing nitrogen by $\mathrm{CO}_{2}$ and $\mathrm{dm} / \mathrm{dt}$ is the rate of fixed carbon loss.

All the experiments in the TG were performed over twice and it was found that the obtained results were similar, revealing that the measured results from the TG were reliable.

\section{Results and Discussions}

\subsection{Samples characterisation}

Proximate and ultimate analyses as well as calorific values of the coals and charcoal, coal rank and petrographic analysis of the single coals are shown in Table 1.
In Table 1, the high volatile matter yield and ultimate analysis results (low elementary carbon, and high $\mathrm{O}$ contents) of $\mathrm{BC}$ agree well with the rank of sub-bituminous coal determined by vitrinite reflectance $(\mathrm{Rr}=0.47 \%)$. The ICA and ICB have medium and low volatile matter respectively and high elementary carbon contents, according to the measured mean vitrinite reflectance values ( 0.92 and $1.39 \%$, respectively). The maceral composition indicates that the three coals are vitrinite-rich (over 75\%), with moderate inertinite content and low or null liptinite content and therefore no significant differences attributable to maceral composition should be expected.

The grindability of coals may also have an impact in the overall selection of the fuel because harder fuels may cause operational problems in the mills or may require higher energy input. $\mathrm{BC}$ has a low HGI value and that means it is harder to grind than the CC, ICA and ICB coals.

The calorific value of a coal affects the coke replacement ratio (RR). The RR is defined as the mass, in kilograms, of coke replaced per kilogram of coal. Generally, the RR increases as coal calorific value increases ${ }^{11}$. Based on the calorific value, the most favourable coals for PCI were both ICA and ICB, which are the coals with the highest calorific value.

As ash content is one of the limitations for the use of coals in PCI, the high ash content of BC (15.7\%) makes its individual use not feasible for PCI. Its high sulfur content (1\%) also invalidates its use as a single coal. The ash content of CC is considerably lower than that of the coals. The low ash content of the $\mathrm{CC}$ positively affects the blast furnace operation. CC has a lower sulphur content compared with coals. The content of sulphur is of high interest for blast furnace process since about 70-95\% of sulphur input enters the furnace from the fuel ${ }^{1}$. These results show that the low ash and sulphur content of the CC make its use attractive when mixing with BC, ICA and ICB. The results of ash composition of major elements in coals and charcoal are shown in Table 2.

The ash composition of BC, ICA and ICB are dominated by $\mathrm{SiO}_{2}$ and $\mathrm{Al}_{2} \mathrm{O}_{3}$, reflecting the high contributions of quartz and clay minerals present in the coals. The high content of these compounds indicates an acidic character of the coals' ashes. On the other hand, ash composition of $\mathrm{CC}$ shows a high amount of $\mathrm{CaO}$ and indicates a basic character of these ashes. The total alkalis content $\left(\mathrm{Na}_{2} \mathrm{O}+\mathrm{K}_{2} \mathrm{O}\right)$ for BC is higher than the ones for ICA, ICB and CC. Phosphorous, another undesirable element for the steel production, is found in acceptable low amounts for BC $(0.05 \%)$. For the ICA, ICB and CC, $\mathrm{P}_{2} \mathrm{O}_{5}$ level is much higher (1.3-1.6\%).

Proximate analysis of the blends is presented in Table 3 . The contents of volatile matter for the coal blends are around 20-30\%, and these values fall within the range used in the steelmaking industry $(10-40 \%)^{1}$. Very high contents of volatile matter increase the gas volumes and yield unstable combustion and coke degradation ${ }^{1}$.

Table 1. Analysis of materials.

\begin{tabular}{|c|c|c|c|c|c|c|c|c|c|c|c|c|c|c|}
\hline \multirow{2}{*}{ Sample } & \multicolumn{3}{|c|}{$\begin{array}{c}\text { Proximate analysis } \\
\text { wt. }(\%)\end{array}$} & \multicolumn{5}{|c|}{$\begin{array}{c}\text { Ultimate analysis } \\
\text { wt. }(\%) \text {, daf }\end{array}$} & \multirow{2}{*}{$\frac{\mathrm{CV}}{\mathrm{kcal. \textrm {kg } ^ { - 1 }}}$} & \multirow{2}{*}{ HGI } & \multirow{2}{*}{$\mathrm{Rr}$} & \multicolumn{3}{|c|}{$\begin{array}{c}\text { Petrographic analysis, } \\
\text { vol. mmf } \%\end{array}$} \\
\hline & $\begin{array}{l}\mathrm{VM} \\
\mathrm{daf}\end{array}$ & $\begin{array}{l}\mathrm{FC} \\
\text { daf }\end{array}$ & $\begin{array}{c}\text { Ash } \\
\mathrm{db}\end{array}$ & $\mathrm{C}$ & $\mathrm{H}$ & $\mathrm{N}$ & $\mathrm{S}_{\mathrm{t}}$ & $\mathrm{O}$ & & & & V & I & $\mathrm{L}$ \\
\hline $\mathrm{CC}$ & 21.8 & 78.2 & 4.6 & 83.7 & 3.1 & 1.1 & 0.1 & 12.0 & 7165 & 79 & & & & \\
\hline $\mathrm{BC}$ & 38.7 & 61.3 & 15.7 & 74.7 & 5.0 & 1.4 & 1.0 & 17.9 & 6110 & 50 & 0.47 & 75.1 & 20.3 & 4.6 \\
\hline ICA & 27.7 & 72.3 & 9.5 & 86.4 & 4.9 & 2.1 & 0.6 & 6.0 & 7545 & 79 & 0.92 & 75.5 & 24.3 & 0.2 \\
\hline ICB & 18.5 & 81.5 & 10.3 & 89.8 & 4.3 & 2.0 & 0.5 & 3.5 & 7635 & 91 & 1.39 & 73 & 25.8 & 0.2 \\
\hline
\end{tabular}

wt. $(\%)$ = Weight Percent; VM = Volatile Matter; FC = Fix Carbon; C = Carbon; H = Hydrogen; N = Nitrogen; S = Sulfur; O = Oxygen; CV = Calorific Value; HGI = Hardgrove Index; Rr = Mean Vitrinite Random Reflectance; V = vitrinite; I = inertinite; L = liptinite; daf = dry-ash-free basis; db = dry basis; vol. $=$ volume percent $\mathrm{mmf}=$ mineral matter-free basis . 
Table 2. Chemical analyses of major elements in coals and charcoal ashes.

\begin{tabular}{crrrr}
\hline & \multicolumn{1}{c}{$\mathrm{CC}$} & \multicolumn{1}{c}{ BC } & ICA & \multicolumn{1}{c}{ ICB } \\
\hline $\mathrm{SiO}_{2}$ & 28.46 & 52.56 & 46.00 & 50.14 \\
$\mathrm{Al}_{2} \mathrm{O}_{3}$ & 3.96 & 22.39 & 25.19 & 26.73 \\
$\mathrm{TiO}_{2}$ & 0.23 & 2.18 & 1.24 & 1.33 \\
$\mathrm{Fe}_{2} \mathrm{O}_{3}$ & 1.95 & 5.95 & 14.61 & 9.03 \\
$\mathrm{MnO}$ & 0.62 & 0.07 & 0.14 & 0.09 \\
$\mathrm{MgO}$ & 4.32 & 1.22 & 1.69 & 1.53 \\
$\mathrm{CaO}$ & 39.46 & 4.24 & 4.12 & 3.91 \\
$\mathrm{Na}{ }_{2} \mathrm{O}$ & 0.12 & 4.67 & 0.21 & 0.41 \\
$\mathrm{~K}_{2} \mathrm{O}$ & 2.40 & 1.39 & 1.22 & 1.04 \\
$\mathrm{P}_{2} \mathrm{O}_{5}$ & 1.29 & 0.05 & 1.64 & 1.55 \\
$\mathrm{SO}_{4}$ & 1.91 & 2.11 & 1.20 & 0.78 \\
$\mathrm{P.F}$ & 15.28 & 3.18 & 2.75 & 3.46 \\
\hline
\end{tabular}

Table 3. Proximate analysis of the blends.

\begin{tabular}{cccc}
\hline \multirow{2}{*}{ Sample } & \multicolumn{3}{c}{ Proximate analysis, wt. (\%) } \\
\cline { 2 - 4 } & $\begin{array}{c}\text { VM } \\
\text { daf }\end{array}$ & $\begin{array}{c}\text { FC } \\
\text { daf }\end{array}$ & $\begin{array}{c}\text { Ash } \\
\text { db }\end{array}$ \\
\hline BC-CC & 27.4 & 72.6 & 10.5 \\
BC-ICA & 30.6 & 69.4 & 12.6 \\
BC-ICB & 26.5 & 73.5 & 13.7 \\
CC-ICA & 24.6 & 75.5 & 7.7 \\
CC-ICB & 20.1 & 79.9 & 7.8 \\
ICA-ICB & 23.0 & 77.0 & 9.9 \\
\hline
\end{tabular}

wt. $(\%)=$ Weight Percent; VM = Volatile Matter; FC = Fix Carbon; $\mathrm{daf}=$ dry-ash-free basis; $\mathrm{db}=$ dry basis.

The reduction in the content of ashes is a very important aspect, both for coals injected in the BF and for the ones used in the power generation. The assembly of the coal mixtures is aimed to reduce the ash contents to around $10 \%$, which is the common value in PCI. As it can be seen, the ash yields drops around $10 \%$, when $\mathrm{BC}$ is blended with $\mathrm{CC}$ in a $50 \mathrm{wt}$. (\%) proportion. In the case of the CC-ICA and CC-ICB blends, the ashes contents decreased even more. High values (around 13\%) were verified when blending BC with ICA and ICB in 50 wt. $(\%)$ proportion.

\subsection{Study on behaviour of coals, charcoal and mixtures using TGA}

A representative graph showing the thermogravimetric curves (TG) of the coals and charcoal is given in Figure 1.

The weight loss during pyrolysis followed the same trend as the volatile matter content of the coals (Table 1), with $\mathrm{BC}$ exhibiting the highest weight losses and ICB the lowest ones. The temperature at which maximum weight loss occurs also followed the expected trend rising from $396{ }^{\circ} \mathrm{C}$ for $\mathrm{BC}$, over $438{ }^{\circ} \mathrm{C}$ for ICA to $450{ }^{\circ} \mathrm{C}$ for $\mathrm{CC}$ and $480{ }^{\circ} \mathrm{C}$ for ICB. The temperature at which pyrolysis occurs depends on the fuel type and the heating rate. The pyrolysis temperature increases with higher coal rank ${ }^{16}$. In the case of $\mathrm{CC}$, its pyrolysis temperature is similar to a coal with equivalent $\mathrm{VM}$ content. The higher pyrolysis temperatures with increasing rank is a well-known fact, and relates with the increased difficulty for the thermal breakdown of the organic matter, associated with the different chemical species constituting the labile phases of low and high rank coals ${ }^{17}$.

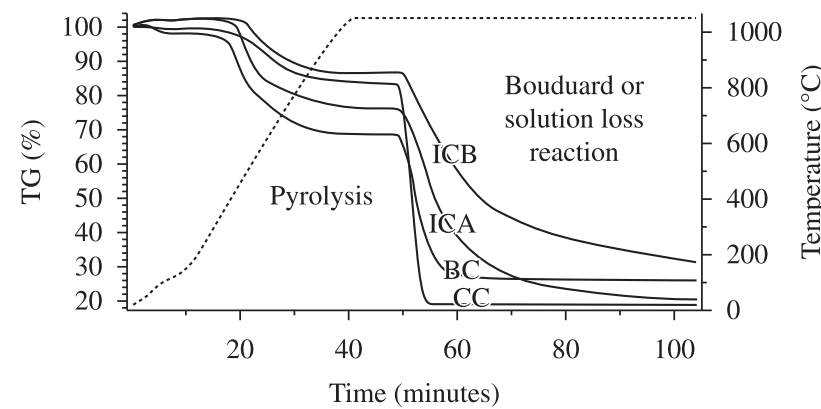

Figure 1. TG curves for coals and charcoal.

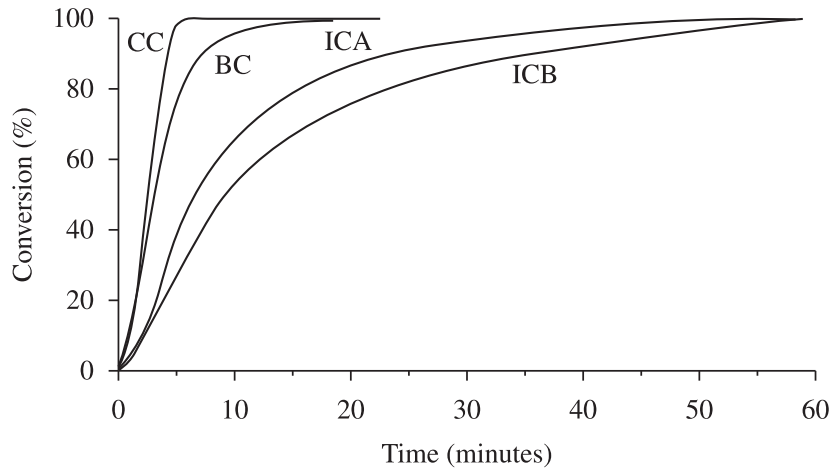

Figure 2. Conversion curves for the coals and charcoal.

Table 4. Experimental maximum reaction rate, time to reach the maximum reaction rate and to reach the $50 \%$ conversion. Calculated maximum reaction rate for the blends assuming additivity.

\begin{tabular}{ccccc}
\hline Sample & $\begin{array}{c}\text { Experimental } \\
\text { maximum } \\
\text { reaction rate } \\
\left(\text { min }^{-1}\right)\end{array}$ & $\begin{array}{c}\text { Time to } \\
\text { reach the } \\
\text { maximum } \\
\text { reaction rate } \\
\text { (minutes) }\end{array}$ & $\begin{array}{c}\text { Time to } \\
\text { reach } \\
50 \% \text { of } \\
\text { conversion } \\
\text { (minutes) }\end{array}$ & $\begin{array}{c}\text { Calculated } \\
\text { maximum } \\
\text { reaction rate } \\
\left(\mathrm{min}^{-1}\right)\end{array}$ \\
\hline CC & 0.22 & 2.67 & 2.3 & \\
BC & 0.16 & 2.33 & 2.8 & \\
ICA & 0.08 & 5.17 & 6.6 & \\
ICB & 0.06 & 5.33 & 9.5 & \\
Blend & & & & \\
CC-ICA & 0.13 & 5.3 & 5.3 & 0.14 \\
BC-ICA & 0.12 & 4.8 & 4.6 & 0.11 \\
BC-CC & 0.11 & 2.3 & 4.4 & 0.20 \\
CC-ICB & 0.10 & 5.0 & 5.4 & 0.13 \\
BC-ICB & 0.10 & 5.0 & 5.8 & 0.10 \\
ICA-ICB & 0.08 & 5.3 & 9.3 & 0.07 \\
\hline
\end{tabular}

The weight loss that begins in around 50 minutes is referring to the Bouduard or solution loss reaction $\left(\mathrm{C}+\mathrm{CO}_{2} \rightarrow 2 \mathrm{CO}\right)$. The conversion curves for coals and charcoal vs. time are given in Figure 2.

The derivative TG curve (DTG) provides the maximum reaction rate of the samples. Table 4 shows the data of the maximum reaction rate and the time to reach the maximum rate for the coals, charcoal and blends. The experimental maximum rates of the blends can be compared to the average maximum rates calculated from pure components. The time to reach $50 \%$ of conversion to the coals and blends can also be seen in Table 4. 
Figure 2 shows that $\mathrm{CC}$ reacts quickly with $\mathrm{CO}_{2}$ and in about 5 minutes all carbon reacted. For BC the time to reach all carbon conversion was around 15 minutes. For ICA and ICB, the times were significantly higher, around 47 and 60 minutes respectively.

$\mathrm{CC}$ has the highest reaction rate (Table 4). It reacts with $\mathrm{CO}_{2}$ faster than the $\mathrm{BC}$, ICA and ICB. The time to reach the maximum rate was similar for $\mathrm{CC}$ and $\mathrm{BC}$, around 2 minutes. For the imported coals, the times were considerably higher, around 5 minutes.

The time required to reach $50 \%$ of carbon conversion is another way of expressing the results obtained in the thermogravimetric tests. In Table 4 it can be seen that the $\mathrm{CC}$ and $\mathrm{BC}$ coals presented the lowest times. For the imported coals, the times were considerably longer.

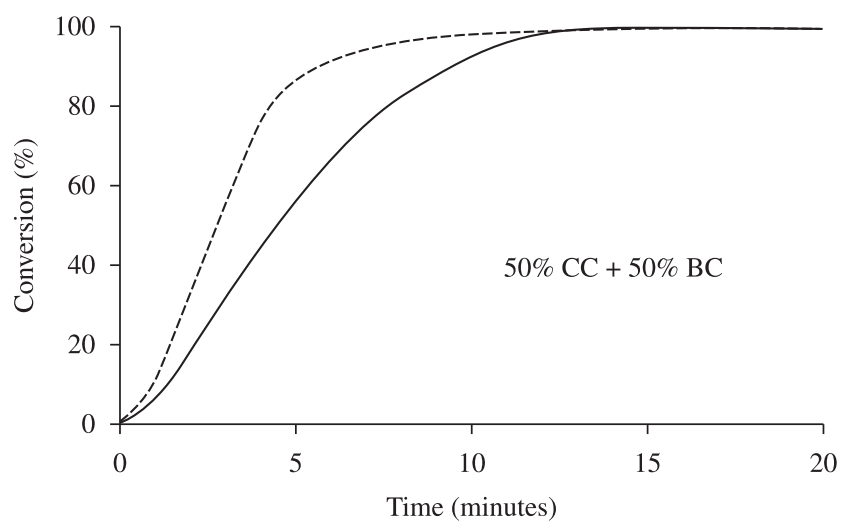

(a)

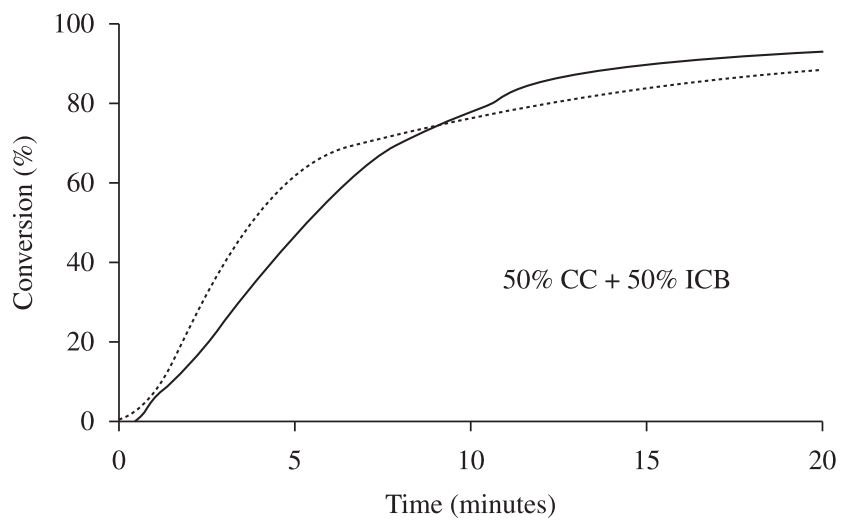

(c)

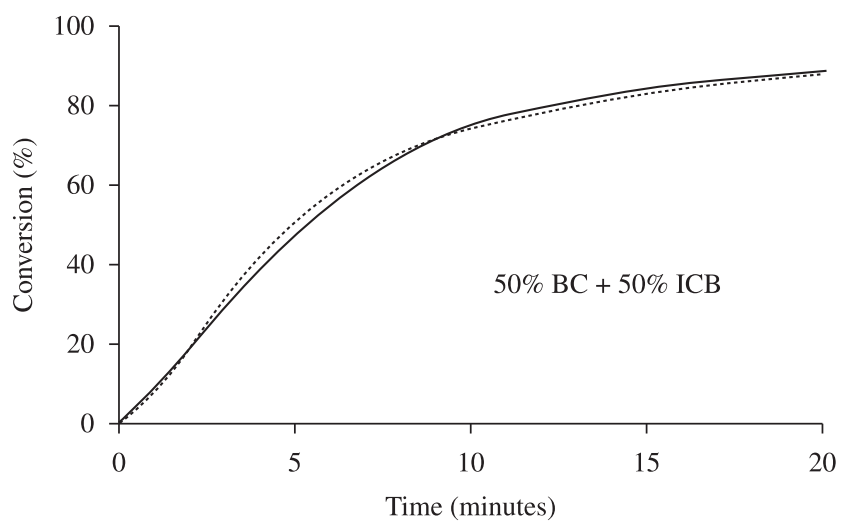

(e)
According to Sami et al. the high reactivity of CC can be explained by its porous and highly disordered carbon structure ${ }^{18}$. The structural disorder may also lead to higher reactivities of biomass since more edge carbon (which is more reactive) is available ${ }^{16}$.

In comparison with the imported coals, ICA and ICB, the high reactivity of $\mathrm{BC}$ is due to its minor rank. During the process of pyrolysis the coals lose volatiles and the carbonaceous residue resolidifies with a structure different to that of the parent coal. In the case of $\mathrm{BC}$, a sub-bituminous coal, the carbonaceous residue maintains a disordered and therefore reactive structure due to the abundant cross-links in the parent coal. ICA and ICB coals pass through a plastic stage during heating and the carbonaceous residue resolidifies with an ordered structure which is less reactive than that of $\mathrm{BC}^{18}$.

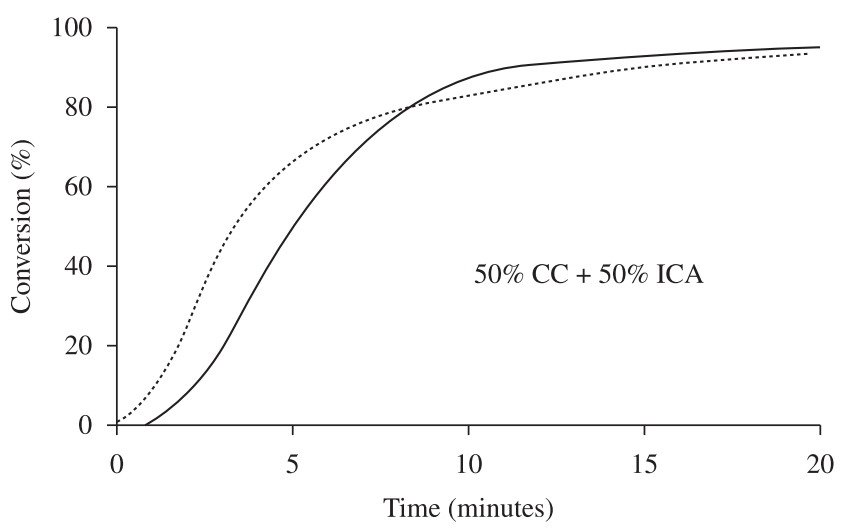

(b)

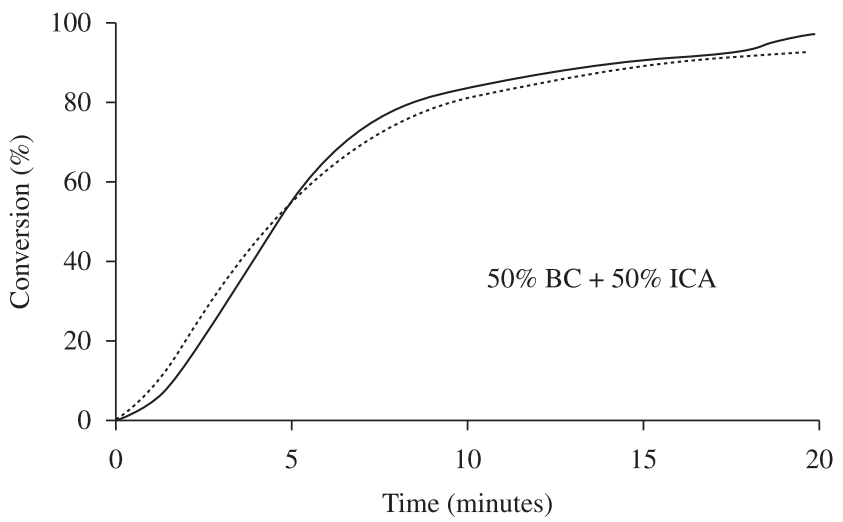

(d)

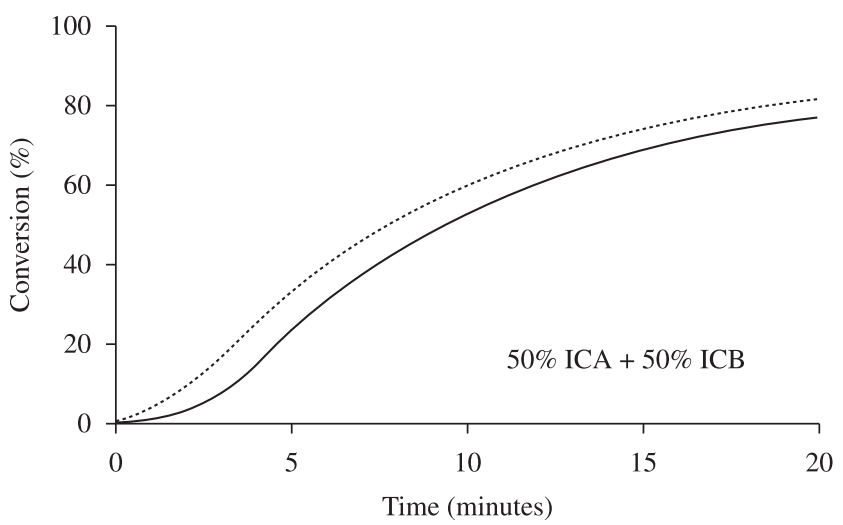

(f)

Figure 3. Conversion curves of the blends. Continuous line: experimental result; dotted line: calculated blend curve. 
The conversion curves for the blends are shown in Figure 3. The average conversion curves calculated from the pure components are also represented as the dotted line in Figure 3.

Experimental conversion of the blend $\mathrm{BC}-\mathrm{CC}$ is lower than that expected from the calculated curve, i.e., a negative deviation is observed (Figure 3, curve a). This non-additive behaviour can also be seen in the maximum reaction rate of the $\mathrm{BC}-\mathrm{CC}$ blend (Table 4). The experimental value $\left(0,110 \mathrm{~min}^{-1}\right)$ was lower than that calculated from the pure components $\left(0,199 \mathrm{~min}^{-1}\right)$.

Although several studies have reported the existence of this type of interaction among the various types of fuel, the cause of this interaction is not clearly understood. Interactions between coal/ biomass, petroleum coke/plastics and lignite/biomass have been published in literature ${ }^{19-24}$

Interactions between the ash and combustible material may occur and this can hinder the gasification of $\operatorname{char}^{25}$. Fusing and melting of ash particles may restrict the accessibility of gas to carbon in the char by physical obstruction. Depending on the chemical composition of the ash, compounds of low melting point may be formed. The possibility that interactions between the mineral matter of the $\mathrm{BC}$ and CC coals has hindered the access of the gas to the char should not be excluded. Machado 2009 showed that large reductions in the ash fusion temperatures occurred when Brazilian coal was mixed with biomass ${ }^{26}$.

In the cases in which $\mathrm{CC}$ is mixed with the highest rank coals (ICA and ICB), the experimental curve shows a lower conversion than the calculated one in the first steps of $\mathrm{CO}_{2}$ gasification (Figure 3 curves $\mathrm{b}$ and $\mathrm{c}$ ). At more advanced stages the experimental curve surpasses the calculated one, indicating a faster reaction. This could be due to the behaviour of these coals during heating. Both coals pass through a plastic stage with low viscosity in which they can surround the solid grains of charcoal. This process will delay the reaction at the beginning until the less reactive surrounding material is consumed and the more reactive charcoal is reached by the $\mathrm{CO}_{2}$. The same phenomena would be operating in the case of $\mathrm{BC}$ blended with the higher rank coals (Figure 3 curves $d$ and e). In these cases the reactivity differences between the higher rank coals and the subbituminous coals are lower.

A statistical method (ANOVA) to evaluate the reactivity differences, time to reach the maximum rate and $50 \%$ conversion of the mixtures (Table 4) led to the following conclusions:

- The blend $\mathrm{BC}-\mathrm{CC}$ does not present the higher reactivity, but it reached the maximum reaction rate in about half the time in comparison with the other blends.

- In the case of the blends of $\mathrm{CC}$ and $\mathrm{BC}$ with imported coals, for the ICA coal, there are no significant differences between the reactivities of the blends with $\mathrm{CC}$ or $\mathrm{BC},\left(\mathrm{R}_{\mathrm{CC}-\mathrm{ICA}}=\mathrm{R}_{\mathrm{BC}-\mathrm{ICA}}\right)$. The same ocurrs with the ICB coal, there are no significant differences between the reactivities of the blends with $\mathrm{CC}$ or $\mathrm{BC},\left(\mathrm{R}_{\mathrm{CC} \text { - ICB }}=\mathrm{R}_{\mathrm{BC} \text { - ICB }}\right)$. The reactivities of the $\mathrm{CC}$ or $\mathrm{BC}$ blends with ICA are significantly higher in relation to the $\mathrm{CC}$ or BC blends with ICB, $\left(\mathrm{R}_{\mathrm{CC}-\mathrm{ICA},} \mathrm{R}_{\mathrm{BC}-\mathrm{ICA}}>\mathrm{R}_{\mathrm{CC}-\mathrm{ICB}}, \mathrm{R}_{\mathrm{BC}-\mathrm{ICB}}\right)$.

- The blend ICA-ICB presents the lower reactivity. The time to reach $50 \%$ of conversion was the largest in comparison with the other blends. In relation to the BC-CC and to the other blends, this time was around 2 and 1.5 times larger respectively.

\section{Final Remarks}

Under the existing injection condition in the BFs, it is known that the unburnt particles generated in the raceway may react outside of this zone, for example, in the furnace shaft with $\mathrm{CO}_{2}$. For the individual coals, based on the TGA tests, it is expected that CC presents a larger reactivity and conversion in the presence of $\mathrm{CO}_{2}$.
Despite the fact that $\mathrm{BC}$ shows a high reactivity and conversion, its individual injection does not seem to be feasible due to its high ash, sulphur and alkalis contents.

The addition of $\mathrm{CC}$ to $\mathrm{BC}$ resulted in a decrease of the blend ash content. A non-additive behaviour was seen in the conversion curve and in the maximum reaction rate of the $\mathrm{BC}-\mathrm{CC}$ blend. Probably interactions between the mineral matter of $\mathrm{BC}$ and $\mathrm{CC}$ coals has hindered the access of the gas to the char. In spite of this, its high reactivity makes its injection into BFs attractive. The injection of this blend is particularly interesting since it enables the use of national coal, and in this way, decreasing the foreign dependence on coals.

In the cases in which coals passing through a plastic stage were blended with a low rank coal or a charcoal a delay in conversion was observed for the early gasification steps, which was compensated after some time. It is possible that this behaviour can be attributed to the formation of an unreactive film during the plastic stage surrounding the reactive particles, then delaying the gasification reaction.

Based on ANOVA, there were no significant differences in the experimental maximum reaction rate between CC-ICA and BC-ICA blends. The same occurred to the CC-ICB and BC-ICB. The blends of the imported coals with $\mathrm{CC}$ are more advantageous because they have a lesser ash content.

As for the chemical composition, the blend of imported coals (ICA-ICB) seems to be appropriate for injection. However, during its gasification behavior in $\mathrm{CO}_{2}$, it was observed that this blend presented a lower reactivity and conversion.

For the optimization of $\mathrm{BF}$ operation with the injection of mixtures of national coal, charcoal and imported coals, further research is needed on the raceway combustion zone.

\section{Acknowlegements}

The authors of this paper would like to thank:

- To CAPES for the financial support.

- To USIMINAS to provided access to imported coals, charcoal and analytical results.

\section{References}

1. Babich A, Senk D, Gudenau HW and Mavrommatis K. Ironmaking. Verlagshaus Mainz GmbH Aachen; 2008.

2. Instituto Brasileiro de Siderurgia. Brazil Steel Databook; 2008.

3. Departamento Nacional de Produção Mineral - DNPM. Informativo Anual da Indústria Carbonífera. Brasilia, Brazil: Ministério de Minas e Energia; 2006. Available from: <http://www.dnpm.gov.br/>.

4. Kalkreuth W, Borrego AG, Alvarez D, Menendez R, Osório E, Ribas M et al. Exploring the possibilities of using Brazilian subbituminous coals for blast furnace pulverized fuel injection. Fuel. 2005; 84:763-772.

5. Osório E, Gomes MLI, Vilela ACF, Kalkreuth W, Almeida MAA, Borrego AG et al. Evaluation of petrology and reactivity of coal blends for use in pulverized coal injection. Coal Geology. 2006; 68:14-29.

6. Gomes MLI, Osório E and Vilela ACF. Thermal analysis evaluation of the reactivity of coal mixtures for injection in the blast furnace. Materials Research. 2006; 9(1):91-95.

7. Sindicato da Indústria do Ferro no Estado de Minas Gerais - SINDIFER. Anuário; 2007. Available from: <http://www.sindifer.com.br/>.

8. Nogami H, Yagi J and Sampaio R. Exergy Analysis of Charcoal Charging Operation of Blast Furnace. ISIJ International. 2004; 44(10):1646-1652.

9. Ironmaking - Energy Saving and Environment in Ironmaking. Online course. Available from: <http://meveus.iehk.rwth-aachen.de/>.

10. Wu L, Paterson N, Dugwell DR and Kandiyoti R. Simulation of BlastFurnace Tuyere and Raceway Conditions in a Wire Mesh Reactor: Extents of Combustion and Gasification. Energy \& Fuels. 2007; 21:2325-2334.

11. Carpenter AM. Use of PCI in blast furnaces; 2006. 
12. Zhu W, Song W and Lin W. Catalytic gasification of char from co-pyrolysis of coal and biomass. Fuel Processing Technology. 2008; 89:890-896.

13. Park $\mathrm{HY}$ and Ahn DH. Gasification kinetics of five coal chars with $\mathrm{CO}_{2}$ at elevated pressure. Korean Journal of Chemical Engineering. 2007; 24(1):24-30.

14. Liu Tie-Feng, Fang Yi-Tian and Wang Y. An experimental investigation into the gasification reactivity of chars prepared at high temperatures. Fuel. 2008; 87:460-466.

15. Goyal A, Zabransky RZ and Rehmat A. Gasification kinetics of western Kentucky bituminous coal char. Industrial \& Engineering Chemistry Research. 1989; 28:1767.

16. Sami M, Annamalai $\mathrm{K}$ and Wooldridge M. Co-firing of coal and biomass fuel blends. Progress in Energy and Combustion Science. 2001; 27:171-214.

17. Solomon PR, Serio MA and Suuberg EM. Coal pyrolysis: experiments, kinetic rates and mechanisms. Progress in Energy and Combustion Science. 1992; 18:133-220.

18. Alonso MJG, Borrego AG, Alvarez D, Menéndez R and Kalkreuth W. Physicochemical transformations of coal particles during pyrolysis and combustion. Fuel. 2001; 80:1857-1870.
19. Ndaji FE, Ellyat WAT, Malik AA and Thomas KM. Temperature programmed combustion studies of the co-processing of coal and waste materials. Fuel. 1999; 78:301-307.

20. Ahmaruzzaman M and Sharma DK. Non-isothermal kinetic studies on co-processing of vacuum residue, plastics, coal and petrocrop. Journal of Analytical and Applied Pyrolysis. 2005; 73:263-275.

21. Yoon SJ, Choi YCS and Lee H. Thermogravimetric study of coal and petroleum coke for co-gasification. Korean Journal of Chemical Engineering, 2007; 24(3):512-517.

22. Audeh CA and Yan TY. Coprocessing of petroleum residue and coal. Industrial \& Engineering Chemistry Research. 1987; 26(12):2419-2423.

23. Haykiri-acma H and Yaman S. Effect of co-combustion on the burnout of lignite/biomass blends: a Turkish case study. Waste Manag. 2008; 28:2077-2084.

24. Osorio E, Ghiggi L, Vilela ACF, Kalkreuth W and Borrego AG. Non-isothermal combustion behaviour of coal blends in a thermobalance as seen by optical microscopy. Thermochimica Acta, 2008; 475:1-8.

25. Lin SY, Hirato M and Horio M. The characteristics of coal char gasification at around ash melting temperature. Energy Fuels. 1994; 8(3):598-606.

26. Machado JGMS. Reactivity and Combustion Behaviour of Brazilian and Imported Coals, Charcoal and Blends. [Thesis]. Porto Alegre: Engineering School, Federal University of Rio Grande do Sul; 2009. 